\title{
Quali-quantitative analysis of adherence and perceived satisfaction of individuals with COPD after high-intensity training on land and in water: additional analysis from a randomized clinical trial
}

Análise quali-quantitativa da aderência e percepção da satisfação de indivíduos com DPOC após treinamento físico de alta intensidade no solo e na água: análises adicionais de um ensaio clinico randomizado

Análisis cuali-cuantitativo de adherencia y percepción de la satisfacción de individuos con EPOC después de entrenamiento físico de alta intensidad en suelo y en agua: análisis adicionales de un ensayo clínico aleatorizado

Débora Rafaelli de Carvalho', Larissa Araújo de Castro ${ }^{2,3}$, Myriam Fernanda Merli ${ }^{4}$, Josiane Marques Felcar ${ }^{5,6}$, Lais Silva Vidotto 7 , Dirce Shizuko Fujisawa ${ }^{8}$, Vanessa Suziane Probst ${ }^{9}$

\begin{abstract}
Although patients with chronic obstructive pulmonary disease (COPD) benefit in many ways after participating in pulmonary rehabilitation programs, high dropout rates are still observed among participants. This study aims to analyze the adherence rate and perceived satisfaction in individuals with chronic obstructive pulmonary disease who underwent high-intensity physical training on land ( $L G$ ) and in water (WG). This study is an additional analysis from a randomized controlled trial. In total, 36 subjects (51\%) completed the intervention. All participants underwent six months of high-intensity endurance and strength training. Adherence was assessed by the proportion of patients who completed the training program. Perceived satisfaction was evaluated using a questionnaire composed of structured and semi-structured questions. The interviews were recorded, transcribed, and analyzed according to the criteria of our thematic analysis. The Shapiro-Wilk test was used to assess data normality, and dropout rates were compared using the chi-square test.
\end{abstract}

Statistical significance was set at 5\%. Regarding adherence, $59 \%$ of WG participants and $44 \%$ of LG participants completed the program, with no difference between the groups ( $p>0.05$ ). Individuals from both groups were equally satisfied after six months of physical training (<90\%); the therapist-patient relationship and treatment effectiveness being important factors for this perception. Qualitative analysis also showed that WG participants reported a more prominent improvement in their respiratory symptoms, leisure, sensation of pain, and sleep. In conclusion, patients with COPD were satisfied after six months of high-intensity physical training in water and on land, noting that water exercising promoted additional benefits compared to land exercising. There seems to be no superiority to any of the regimens (water or land) regarding the adherence to the training programs.

Keywords | Chronic Obstructive Pulmonary Disease; Rehabilitation; Exercise; Patient Acceptance of Health Care; Patient Compliance.

\footnotetext{
Study conducted at the Centro de Ciências da Saúde, Universidade do Norte do Paraná (UNOPAR) - Londrina (PR), Brazil. Universidade Estadual de Londrina (UEL) - Londrina (PR), Brasil. E-mail: debora_rafaelli@yahoo.com.br. ORCID-0000-0001-9812-1780 2Universidade Estadual de Londrina (UEL) - Londrina (PR), Brasil. E-mail: larissa.decastro@yahoo.com.br. ORCID-0000-0002-0835-3906 3Universidade do Norte do Paraná (UNOPAR) - Londrina (PR), Brasil. E-mail: larissa.decastro@yahoo.com.br. ORCID-0000-0002-0835-3906

${ }^{4}$ Universidade do Norte do Paraná (UNOPAR) - Londrina (PR), Brasil. E-mail: myriamerli@hotmail.com. ORCID-0000-0001-9379-787X 5Universidade Estadual de Londrina (UEL) - Londrina (PR), Brasil. E-mail: josianefelcar@gmail.com. ORCID-0000-0003-3270-6940 6Universidade do Norte do Paraná (UNOPAR) - Londrina (PR), Brasil. E-mail: josianefelcar@gmail.com. ORCID-0000-0003-3270-6940 7Universidade Estadual de Londrina (UEL) - Londrina (PR), Brasil. E-mail: laisvidotto@outlook.com. ORCID-0000-0002-9500-6223 8Universidade Estadual de Londrina (UEL) - Londrina (PR), Brasil. E-mail: dirce07@sercomtel.com.br. ORCID-0000-0001-8427-2860 'Universidade Estadual de Londrina (UEL) - Londrina (PR), Brasil. E-mail: vanessaprobst@gmail.com. ORCID-0000-0003-1483-5319
} 
RESUMO | Embora os pacientes com doença pulmonar obstrutiva crônica (DPOC) se beneficiem de muitas maneiras de programas de reabilitação pulmonar, ainda são observadas altas taxas de desistência entre os participantes. O objetivo deste estudo foi analisar a taxa de adesão e a percepção de satisfação de indivíduos com DPOC que realizaram treinamento físico de alta intensidade em solo (GS) e água (GA). Foram realizadas análises adicionais de um ensaio clínico randomizado. 36 indivíduos (51\%) completaram a intervenção. Todos os participantes foram submetidos a seis meses de treinamento de força e resistência de alta intensidade. A adesão foi avaliada pela proporção de pacientes que completaram o programa de treinamento e a satisfação foi avaliada por meio de um questionário composto por questões estruturadas e semiestruturadas. As entrevistas foram gravadas, transcritas e analisadas de acordo com o critério de análise de conteúdo. Foi utilizado o teste de Shapiro-Wilk para avaliar a normalidade dos dados e o teste qui-quadrado para a comparação da taxa de aderência. Foi adotado $\mathrm{p}<0,05$ como significância estatística. Em relação à adesão, 59\% dos participantes do GA e 44\% do GS completaram o programa, sem diferença entre os grupos ( $p>0,05)$. Os indivíduos de ambos os grupos estavam igualmente satisfeitos após seis meses de treinamento físico (<90\%), sendo a relação terapeuta-paciente e a eficácia no tratamento fatores importantes para essa percepção. A análise qualitativa também mostrou que os participantes do GA relataram benefícios mais proeminentes em relação aos sintomas respiratórios, ao lazer, a sensação de dor e ao sono. Portanto, os pacientes com DPOC se mostraram satisfeitos após seis meses de treinamento e perceberam que o exercício na água promoveu mais benefícios do que em solo. Em relação à adesão aos programas de treinamento não pareceu haver superioridade de nenhum dos regimes (água ou solo).

Descritores | Doença Pulmonar Obstrutiva Crônica; Reabilitação; Exercício; Satisfação do paciente; Cooperação e Adesão ao Tratamento.
RESUMEN | Aunque los programas de rehabilitación pulmonar ayudan a los pacientes con enfermedad pulmonar obstructiva crónica (EPOC), todavía se observan altas tasas de abandono de los participantes en estos programas. El objetivo de este estudio fue evaluar la tasa de adherencia y la percepción de satisfacción de las personas con EPOC que realizaron entrenamiento físico de alta intensidad en suelo (GS) y en agua (GA). Se realizaron análisis adicionales de un ensayo clínico aleatorizado. 36 participantes (51\%) completaron la intervención. Todos se sometieron a seis meses de entrenamiento de fuerza y resistencia de alta intensidad. La adherencia se evaluó por la proporción de pacientes que completaron el programa de entrenamiento, y la satisfacción se evaluó mediante un cuestionario con preguntas estructuradas y semiestructuradas. Las entrevistas fueron grabadas, después transcritas y analizadas según el criterio de análisis de contenido. Para evaluar la normalidad de los datos, se utilizó el test de Shapiro-Wilk, y para comparar la tasa de adherencia se aplicó la prueba de chi-cuadrado. El nivel de significación estadística fue de $p<0,05$. En cuanto a la adherencia, el 59\% de los participantes del GA y el 44\% del GS completaron el programa, sin diferencia entre grupos ( $p>0,05)$. Ambos grupos estaban igualmente satisfechos después de seis meses de entrenamiento físico (<90\%), por lo que la relación terapeuta-paciente y la eficacia del tratamiento fueron los factores importantes de esta percepción. El análisis cualitativo también apuntó que los participantes de GA informaron más beneficios con respecto a los síntomas respiratorios, el ocio, la sensación de dolor y el sueño. Por lo tanto, los pacientes con EPOC estaban satisfechos después de seis meses de entrenamiento y se dieron cuenta de que el ejercicio en el agua les brindaba más beneficios que el ejercicio en el suelo. En cuanto a la adherencia al carácter de los programas de entrenamiento (si agua o suelo), no pareció haber superioridad en ninguno de ellos.

Palabras clave | Enfermedad Pulmonar Obstructiva Crónica; Rehabilitación; Ejercicio; Satisfacción del paciente; Cumplimiento y Adherencia al Tratamiento.

\section{INTRODUCTION}

Chronic obstructive pulmonary disease (COPD) is associated with several respiratory and non-respiratory manifestations, such as dyspnea, muscle weakness, and reduced levels of physical activity in daily life (PADL) $)^{1-3}$. The benefits of pulmonary rehabilitation (PR) for these individuals are already established; they include improvements in exercise capacity, muscle strength, overall symptoms, and quality of life, ${ }^{4-5}$ even though high dropout rates are often observed $^{6}$, which possibly minimize its positive effects.
Low adherence is considered multifactorial, and acute symptom exacerbation, psychological problems, and transportation difficulties have been recognized as its determinants ${ }^{7-10}$. Other factors may also influence adherence rates and have not yet been investigated in this population - for instance, training environment and perceived satisfaction.

Conventional training programs for individuals with COPD are composed of endurance and strength exercises, performed using cycle ergometers, treadmills, and multigym stations ${ }^{6}$. Training in water could be an 
alternative to increase adherence, since the modality seems to promote socialization in a more recreational environment ${ }^{11-12}$. Water-based training has similar or greater benefits than land-based training. ${ }^{13-15}$ Besides, water's properties reduce the inherent risk of musculoskeletal injuries due to impact ${ }^{16}$.

The perceived satisfaction in relation to the offered treatment may be an interesting measure to better understand the provided health services and patients' expectations, which can be useful to elaborate strategies to increase adherence ${ }^{17-19}$.

The degree of perceived satisfaction of COPD patients undergoing high-intensity physical training in aquatic and land environments is not yet known, and whether the aquatic option can influence the treatment's adherence rate has been little investigated. It can be hypothesized that higher degrees of perceived satisfaction may increase adherence and, consequently, result in greater treatment benefits. Therefore, this study aims to analyze adherence and perceived satisfaction in individuals with COPD who underwent high-intensity physical training on land and in water.

\section{METHODS}

\section{Study design and sample}

This qualitative and quantitative study was part of a larger randomized clinical trial ${ }^{15}$ (registered on ClinicalTrials.gov under number NCT01691131), conducted according to CONSORT criteria, in the period between July 2011 and October 2014, which aimed at comparing the effects of exercise training on land and in water in patients with COPD. The study was conducted according to COREQ criteria.

The sample consisted of individuals diagnosed with $\mathrm{COPD}^{1}$; who were stable (i.e., no severe exacerbations in the previous three months); aged $\geq 50$ years old; without comorbidities that might have interfered in the evaluations; and did not follow any exercise program in the previous year. Exclusion criteria were: high and uncontrolled blood pressure; inability to tolerate hydrotherapy, and severe exacerbations.

Randomization was performed in two stages: generation of numbers (table of random numbers) and blind allocation (opaque and sealed envelopes) ${ }^{15}$. Subjects were then allocated into two groups: a Land
Group (LG) and a Water Group (WG). Both training protocols (land- and water-based) were previously demonstrated to be effective in improving quality of life, exercise capacity, muscle strength, and physical activity in daily life ${ }^{15}$. Due to the intervention characteristics, it was not possible to blind participants and therapists who implemented the training. The outcome raters were not informed of the allocation of patients into their respective groups.

\section{Procedures}

Initially, comorbidity history and sociodemographic data were collected. Weight and height were measured, and body mass index (BMI) was then calculated $\left(\mathrm{kg} / \mathrm{m}^{2}\right)$.

\section{Pulmonary Function}

Pulmonary function was assessed by spirometry (Pony FX, Cosmed, Italy), according to international standards ${ }^{20}$ and considering the reference values for the Brazilian population $^{21}$.

\section{Intervention}

The exercise-training program was performed on land or in water according to the randomization. For both groups, each session lasted one hour and was composed of a warm-up (a one-minute walk, and metabolic exercises for the upper limbs), endurance training (cycling and walking at a pace dictated by a sound stimulus - metronome), strength training of upper (biceps and triceps) and lower limbs (quadriceps), and general stretching (trunk, upper and lower limbs). All sessions were performed on the same period of the day (in the afternoon), for 24 weeks (three sessions per week in the first three months and two sessions per week in the last three months), for a total of 60 sessions. Educational sessions were conducted along with the program and covered the following topics: COPD information; physical training in COPD; guidelines on how to use the inhaled medication; COPD psychological factors; financial aspects; daily life activity; and energy conservation techniques and nutritional factors in COPD.

For the LG, endurance training was comprised of walking on flat ground and cycling. The initial walking intensity was set to $75 \%$ of the average speed achieved in the six-minute walk test (6MWT), and the initial cycling intensity was $60 \%$ of the maximum workload, also based 
on the $6 \mathrm{MWT}^{22}$. The initial strength training load was set to $70 \%$ of the one-repetition maximum test (1RM). Symptoms ranging from four to six in the modified Borg scale were considered targets for intensity determination ${ }^{23}$.

For the WG, the exercise training was conducted in a heated pool $\left(33^{\circ} \mathrm{C}\right)$. The initial walking intensity was set to $75 \%$ of the average speed achieved in the $6 \mathrm{MWT}$ divided by three ${ }^{24}$, and the cycle training's target intensity was the effort perception between four and six points according to the modified Borg scale ${ }^{23}$. The strength training initial load was set to $70 \%$ of the $1 \mathrm{RM}$ plus $14 \%$, in order to match the weight used for the LG. The adjustment was made by a physicist and considered the physical properties of water and the density of the wrist/ankle weights (iron grit) ${ }^{15}$.

More details regarding the two training regimens can be found elsewhere ${ }^{15}$.

\section{Analysis of adherence to training programs}

Participants who completed 24 weeks of training and attended re-evaluation were considered adherent, and those who stopped attending the training (even after three phone calls), were identified as dropouts. Their reasons for dropping out were also investigated.

\section{Interview on satisfaction}

The interview was performed using a questionnaire containing structured and semi-structured questions regarding the participants' perceived satisfaction in relation to the program, based on the guidelines of the "Qualitative Research Guideline Project" 25 . The questionnaire was submitted to two experts - one with experience in qualitative studies and another with experience in clinical practice in the specific area. It was also submitted to all students of a specific subject - "Qualitative approach related to research" - in the Rehabilitation Sciences' master's program at the Universidade Estadual de Londrina, who had prior knowledge of the development of interview questionnaires. After that, adjustments were made concerning the questions structure and sequence. Subsequently, a pilot study was conducted with its first three subjects to check if the questions achieved the proposed objectives, and to train the interviewer.

The final questionnaire contained seven questions, and each one of them was comprised of a structured component and a semi-structured component (online supplementary material). These questions related to the obtained results, prescribed exercises, symptoms, activities of daily living (ADL), therapist-patient relationship and preference of a training environment (water or land) before starting, and after finishing the program. Except for those questions on preference, the structured component was a Likert scale ranging from -3 (very dissatisfied) to +3 (very satisfied) ${ }^{26}$. In order to facilitate statistical analysis, the scale ranged from 0 (very dissatisfied) to 6 (very satisfied). The semi-structured component was collected with an authorized audio recording of patients' speech, enabling the most reliable transcript of their report. A trained physical therapist carried out the interviews, and an appropriate environment was guaranteed, i.e., a quiet and comfortable room. All patients who completed six months of training were interviewed, and those who had left the program were also sought for interviewing.

\section{Data analysis}

Quantitative analysis was performed with GraphPad 6.0. (GraphPad Software Inc., San Diego, CA, USA). Data normality was verified with the Shapiro-Wilk test, and parametric or non-parametric statistics were used according to data distribution. Dropout rates were compared using the chi-square test. Statistical significance was set to $5 \%$.

For qualitative analysis (semi-structured component), 20 participants were interviewed, 10 randomly selected participants of each group. The interviews were conducted, recorded, and transcribed by a trained examiner. After reading the transcripts, categories were developed, and then judged by two independent raters. Qualitative data were subjected to content analysis according to $\operatorname{Bardin}^{27}$. The five categories were: (1) Preference for a training environment; (2) Feelings when performing the exercises; (3) Symptoms; (4) Therapist-patient relationship; and (5) Satisfaction with the overall program. The quotations deemed most representative of these categories were used to present them to patients. To ensure their confidentiality, LG subjects were described by the letter "L" and WG', by the letter "W," followed by their interview order number.

\section{RESULTS}

Out of the 182 individuals who sought the program, 70 matched the inclusion criteria and were randomized (Figure 1). Baseline characteristics were similar between groups (Table 1). 


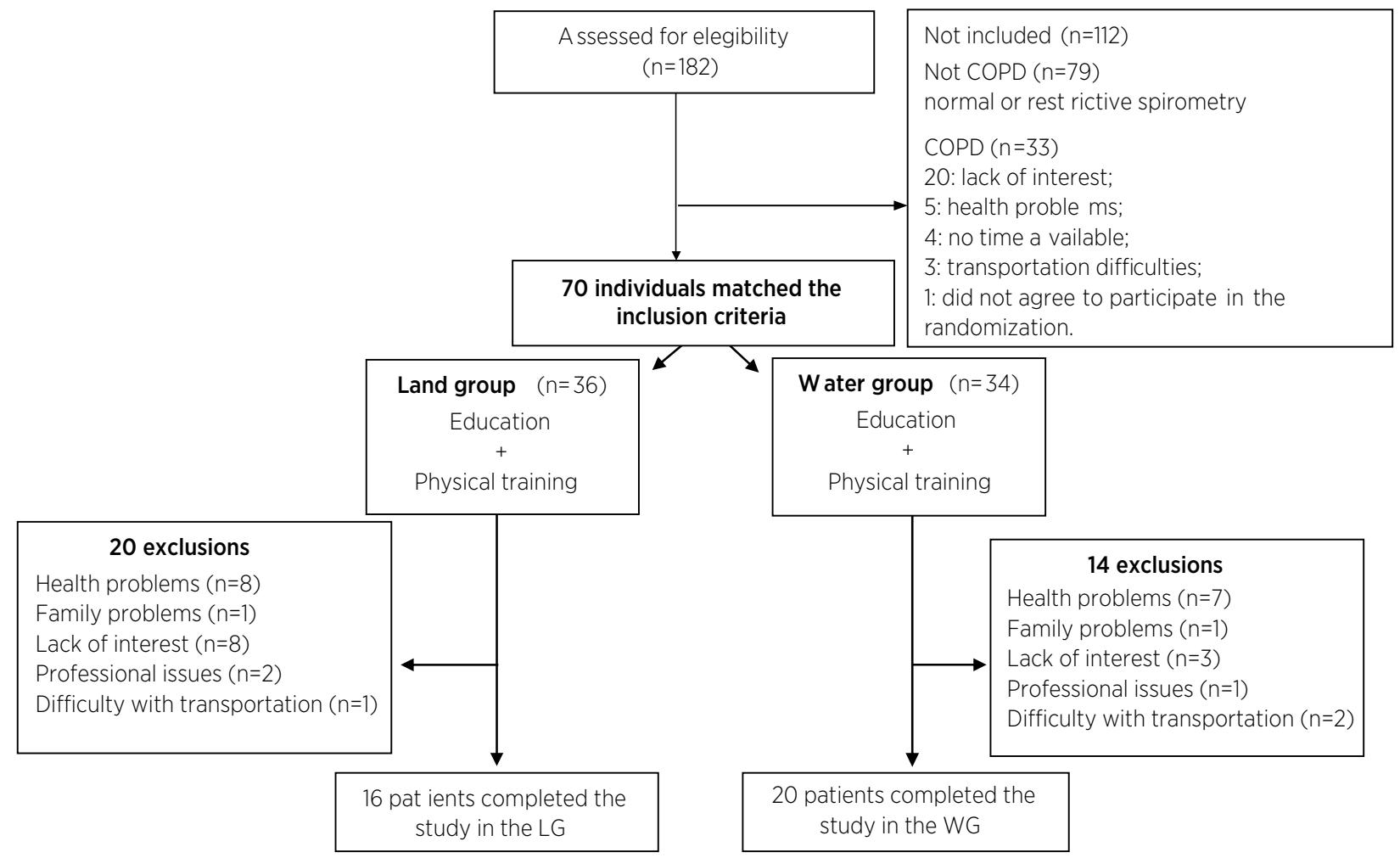

Figure 1. Study flowchart

LG: land group; WG: water group.

Table 1. Baseline characteristics of the participants

\begin{tabular}{|c|c|c|c|}
\hline & $\begin{array}{l}\text { Land group } \\
\quad(n=36)\end{array}$ & $\begin{array}{c}\text { Water group } \\
(n=34)\end{array}$ & p \\
\hline Gender (M/F) & 20/16 & $23 / 11$ & 0.29 \\
\hline Age (years) & $67 \pm 8$ & $69 \pm 8$ & 0.24 \\
\hline Weight (kg) & $69 \pm 15$ & $66 \pm 12$ & 0.44 \\
\hline Height (m) & $1.62 \pm 0.08$ & $1.61 \pm 0.07$ & 0.60 \\
\hline $\mathrm{BMI}\left(\mathrm{kg} / \mathrm{m}^{2}\right)$ & $26 \pm 5$ & $25 \pm 5$ & 0.67 \\
\hline \multicolumn{4}{|l|}{ Lung Function } \\
\hline FVC (\% pred) & $63 \pm 15$ & $66 \pm 14$ & 0.39 \\
\hline $\mathrm{FEV}_{1}(\%$ pred $)$ & $46 \pm 14$ & $48 \pm 16$ & 0.51 \\
\hline $\mathrm{FEV}_{1} / \mathrm{FVC}(\%)$ & $56 \pm 8$ & $56 \pm 10$ & 0.96 \\
\hline \multicolumn{4}{|l|}{ Comorbidities } \\
\hline Musculoskeletal (n) & 11 & 8 & 0.69 \\
\hline Cardiovascular (n) & 23 & 18 & 0.35 \\
\hline Home oxygen (n) & 0 & 0 & - \\
\hline Exacerbations (n) & 11 & 6 & 0.32 \\
\hline Live alone (n) & 6 & 6 & 0.83 \\
\hline Professionally active $(n)$ & 14 & 10 & 0.55 \\
\hline Retired (n) & 26 & 22 & 0.67 \\
\hline Individual income $(\mathrm{R} \$)$ & 1.183 .00 & 1.604 .00 & 0.96 \\
\hline Family income $(R \$)$ & 1.719 .00 & 2.398 .00 & 0.46 \\
\hline \multicolumn{4}{|l|}{ Main dropout reasons } \\
\hline Health problems & $8(40 \%)$ & $7(50 \%)$ & 0.72 \\
\hline Lack of interest & $8(40 \%)$ & $3(22 \%)$ & 0.29 \\
\hline Professional issues & $2(10 \%)$ & $1(7 \%)$ & 0.99 \\
\hline Transportation difficulties & $1(5 \%)$ & $2(14 \%)$ & 0.55 \\
\hline Family problems & $1(5 \%)$ & $1(7 \%)$ & 0.99 \\
\hline
\end{tabular}

Data are expressed as mean \pm standard deviation or absolute values and percentages. M: male; F: female; BMl: body mass index; FVC: forced vital capacity; FEV; forced expiratory volume in the first second \%pred: percentage of the predicted value; n: number of patients; R\$: Brazilian real; Main dropout reasons: 20 participants randomized to $L G$ and 14 randomized to $W G$ failed to complete the program
In total, thirty-six participants completed the exercisetraining program. Twenty participants randomly allocated to $\mathrm{LG}(55 \%)$ and 14 , to WG (41\%) failed to complete the program. There was no difference in the dropout rates between groups $(p>0.05)$. The main dropout reasons are described in Table 1. For both groups, baseline characteristics did not differ between participants who completed the program and those who dropped out $(\mathrm{p}>0.05)$.

Regarding participants' preference for a training environment, both groups expressed increased preference for the same type of training for which they were randomized. However, this increase was more prominent in the WG since the most patients from this group reported preference in continuing in the same treatment environment (Figure 2).

Concerning participants' perceived satisfaction in relation to different aspects of both training regimens, most subjects ( $>90 \%)$ proved to be moderately to very satisfied - according to the Likert scale (Figure 3).

Individuals who had dropped out from the training program were contacted to answer the questionnaire on their perceived satisfaction (Likert scale). Among them, 6 WG patients and 13 LG's were located. WG participants had a higher preference for the same training environment (50\%) when compared to those from LG (30\%). When asked about their perceived satisfaction until the moment of discontinuation, participants from 
both groups reported being moderately to very satisfied in all aspects of the questionnaire. Moreover, perceived satisfaction was similar between participants who dropped out and those who completed the program.

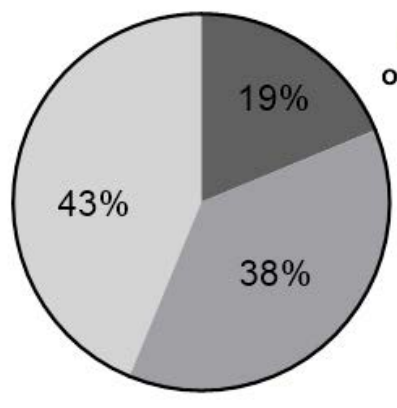

LG

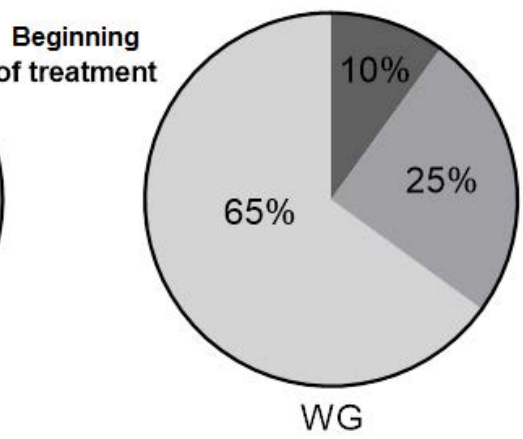

WG

No preference

Preference for the other type of training in which they were not randomized $\square$ Preference for the same type of training in which they were randomized

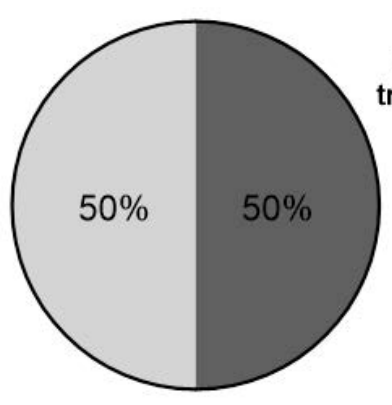

LG

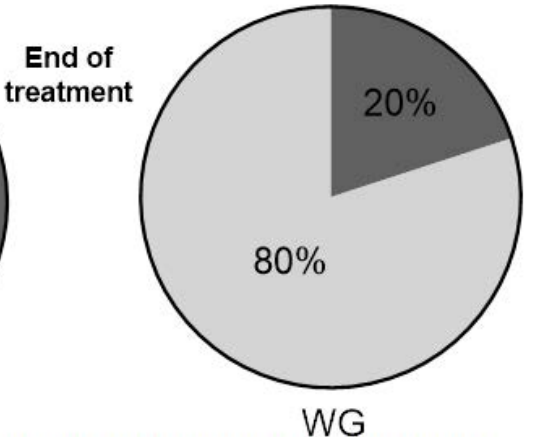

WG

Preference for the other type of training in which they were not randomized

Preference for the same type of training in which they were randomized

Figure 2. Participants' preference for training environments LG: land group; WG: water group.
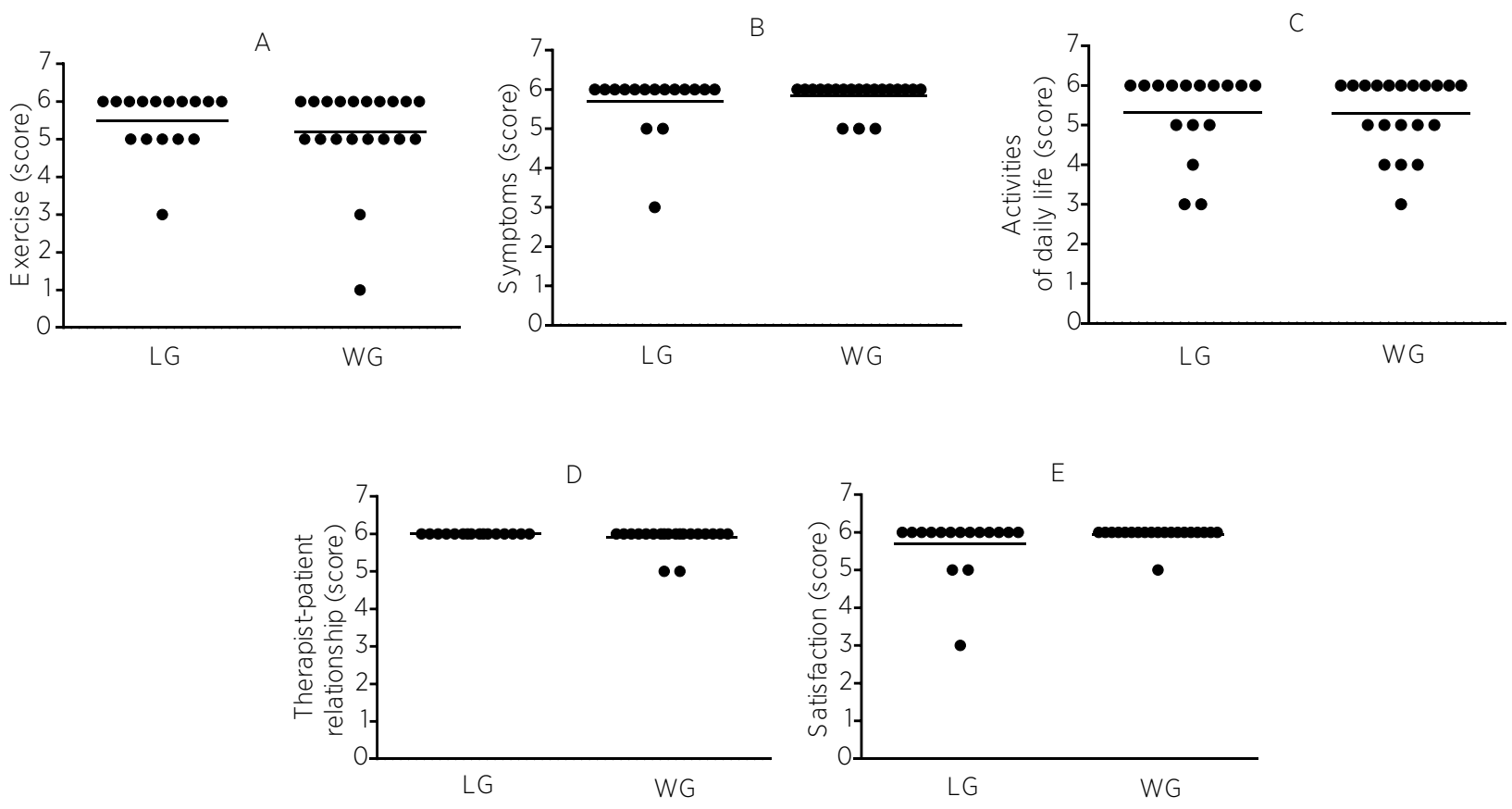

Figure 3. Degree of participants' perceived satisfaction of the exercise-training program factors LG: land group; WG: water group. 
Regarding the preference for a training environment, qualitative analysis showed that WG subjects preferred the same type of training:

"I have always liked water. If I see a pool that I can get into, I'm already in." (W10)

"Same preference since I have always loved water. I have already undergone hydrotherapy." (W4)

On the other hand, participants from LG did not report preference for the same type of training based on the environment:

"I prefer the land environment, because I think that training in water is more intense." (L6)

"Because I like water and thought it would be better."(L8)

Participants from both groups had positive feelings when performing the exercises:
"All exercises were nice." (L1)
"It was very pleasant and enjoyable. I like physical activity; it was very nice to do these activities." (L7)
"Because exercise is good. I love working out." (W2)
"I felt good. I did not have any problems." (W7)

When questioned about their symptoms, participants reported improvements in dyspnea sensation, fatigue, pain, and performance in activities of daily living (Figure 4). The benefits mentioned by LG subjects are described below:

"Now I can run without shortness of breath or fatigue."(L1)

"My body has improved; my legs are less tired." (L5)

It is possible to notice that $\mathrm{WG}$ participants reported more prominent benefits concerning respiratory symptoms, leisure, sleep, and pain sensation:

"I am more willing to go out, go shopping and buy clothes." (W3)

"It improved my body, the strength in my legs, my appetite, sleep and my mood." (W2)

In the therapist-patient relationship category, both groups declared being satisfied with the received care:

"Wow, it was great, all therapists are wonderful, patient, understanding, caring. If I could, I would not leave here."(L6)
"I received much attention, the therapists did everything they could to help me."(W7)

Finally, participants from both groups were satisfied with the overall program and attributed their feeling of well-being to the offered treatment:

"The program was very good for me."(W1)

"I feel more satisfied with the health I have now than before."

(L8)

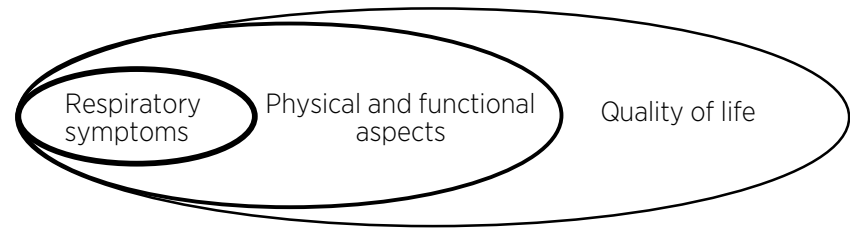

Figure 4. Scope of benefits reported by participants

\section{DISCUSSION}

This study demonstrated that the adherence of individuals with COPD to training on land and in water is similar. Furthermore, participants were moderately to very satisfied with both training programs. Qualitative analysis showed that patients who trained in water reported more prominent benefits than those who trained on land.

In this study, the total sample dropout rate was $49 \%$, with no difference between groups. Although this is a high dropout rate, it is not in full discordance with the literature. Cote and Celli ${ }^{28}$ found a $26 \%$ dropout rate in a pulmonary rehabilitation program with similar structures (physical training plus educational sessions) and Probst et al. ${ }^{29}$ had a dropout rate of $37 \%$ in their program. Despite the lower rates, the shorter duration of those programs (three months) should be considered in contrast to the longer nature of our study (six months). Therefore, a higher dropout rate should be expected. Focused on water-based training, de Souto Araujo et al. ${ }^{13}$ found a dropout rate of $43 \%$ in their sample, while this study dropout rate was higher (59\%). However, a low-intensitity training program was provided in that study, which might have also influenced adherence.

In our study, the main reasons for dropping out were: health problems, professional routine, and lack of interest. Interestingly, even those participants who reported a lack of interest stated they were moderately to very satisfied with the offered treatment. Despite being satisfied, these individuals do not seem to prioritize their rehabilitation, possibly because, in their point of view, the symptoms intensity does not demand an intervention. 
A deeper investigation of this specific group could provide helpful information on how to increase adherence to rehabilitation programs.

At the end of the program, most participants from the WG and half from the LG would rather attend the training in an aquatic environment, i.e., both groups increased their preference for water-based exercise training. It is reasonable to expect that participants' preferences could interfere in adherence. However, dropout rates were not different between LG and WG, demonstrating that preference was not the major factor for adherence in this sample. In the study conducted by McNamara et al. ${ }^{12}$, participants listed staff support and a sense of achievement as key factors for adhering to training in an aquatic environment, showing that other aspects could possibly supplant the preference for a specific training environment. Water training is a relatively new concept in the care of COPD patients; therefore, the influence of preference for an environment of training (water or land) on dropout/adherence rates had not yet been explored.

McNamara et al. ${ }^{12}$ investigated the aquatic environment acceptability for exercise training by people with COPD and physical comorbidities, and found a high acceptability. The authors also observed that $89 \%$ of participants indicated they would continue with water-based exercises, similarly to our study, in which $80 \%$ of WG participants would prefer to continue with water-based exercises. Since patients in this study also showed some degree of comorbidity, the increase of preference for the aquatic environment is reasonable. Rae and White assessed the acceptance of individuals with mild to moderate COPD to aquatic exercises ${ }^{11}$.In their study, most patients reported that training in water was a pleasant experience, and an opportunity to overcome fears and to socialize with people who suffer from the same disease.

When analyzing participants' perception of the program, it was possible to notice that those from WG reported additional benefits (qualitative analysis). This finding is in accordance with another study, in which water-based training promoted greater improvements in the quality of life and exercise capacity of patients with COPD than land-based training ${ }^{14}$. Water training seems to be an attractive alternative for individuals with COPD plus comorbidities ${ }^{14}$, especially orthopedic, since these comorbidities can potentially interfere in the results obtained with conventional PR performed on land ${ }^{30}$. Besides impacting joints less, water training can induce relaxation due to water's physical properties, resulting in additional benefits ${ }^{16}$.
The therapist-patient relationship can be an important tool for developing rehabilitative strategies ${ }^{31}$. Additionally, treatment adherence is likelier when there is a friendly and respectful therapist-patient relationship ${ }^{31}$. Indeed, 93\% of participants, enrolled in a study that investigated the aquatic environment acceptability for exercise-training people with COPD, listed staff support as one of the most significant factors for adherence ${ }^{12}$. In this study, all subjects mentioned their satisfaction with the care provided by the therapists. Therefore, it is possible to infer that this factor played an important role in participants' perceived satisfaction and, consequently, in adherence.

Finally, it was observed that patients from both groups were moderately to very satisfied with the overall program. This finding is in accordance with the study developed by Soufi et al. ${ }^{32}$, in which most participants were satisfied with the provided treatment. Several aspects seem to be involved in this perceived satisfaction, including therapist-patient relationship, treatment effectiveness, and demographic and socioeconomic characteristics ${ }^{32-34}$. The results of our study also suggest that perceived satisfaction is multifactorial since therapist-patient relationship and treatment effectiveness influenced this perception.

The small sample size can be considered a limitation. However, as is recommended for qualitative studies, data saturation was achieved, guaranteeing truthful analyses ${ }^{35}$. On the other hand, this study adds knowledge about adherence and perception of satisfaction of patients with COPD after two similar high-intensity training programs performed in different environments (water and land). The combined analytical methodology (quanti/ qualitative) enables the evaluation of perceived satisfaction and provides evidence of the factors involved in the perception of satisfaction. As a clinical implication of this study, considering the high dropout rates from training programs observed in patients with COPD, it is important to consider patients' preferences before the rehabilitation setup. This could be the focus of future studies in order to verify if preferences would result in greater adherence rates and, consequently, more benefits in terms of exercise capacity and quality of life for this population.

\section{CONCLUSION}

This study demonstrated that adherence was similar among individuals with COPD who underwent highintensity training on land and in water. Participants were satisfied with both training programs, therapist-patient 
relationship and treatment effectiveness being important factors for this perception. Finally, the qualitative analysis showed that patients who trained in water had more prominent benefits when compared to those who trained on land.

It was developed by Débora Rafaelli de Carvalho (study's design, research, methodology, project administration and original draft), Larissa Araujo de Castro (research and writingoriginal draft), Myriam Fernanda Merli (research), Josiane Marques Felcar (research), Lais Silva Vidotto (research), Dirce Shizuko Fujisawa (design, research, methodology and final editing), Vanessa Suziane Probst (design, research, methodology and final editing).

\section{REFERENCES}

1. Global Initiative for Chronic Obstructive Lung Disease. Global strategy for the diagnosis, management and prevention of chronic obstructive pulmonary disease. NHLBI/WHO Workshop Report. Bethesda: National Heart, Lung and Blood Institute; 2001.

2. Gan WQ, Man SF, Senthilselvan A, Sin DD. Association between chronic obstructive pulmonary disease and systemic inflammation: a systematic review and a meta-analysis. Thorax. 2004;59(7):574-80. doi: 10.1136/thx.2003.019588.

3. Celli BR, Cote CG, Marin JM, Casanova C, Montes de Oca M, Mendez RA, et al. The body-mass index, airflow obstruction, dyspnea, and exercise capacity index in chronic obstructive pulmonary disease. N Engl J Med. 2004;350(10):1005-12. doi: 10.1056/NEJMoa021322.

4. Lacasse Y, Brosseau L, Milne S, Martin S, Wong E, Guyatt GH, et al. Pulmonary rehabilitation for chronic obstructive pulmonary disease. Cochrane Database Syst Rev. 2002;(3):CD003793. doi: 10.1002/14651858.CD003793.

5. Nici L, Donner C, Wouters E, Zuwallack R, Ambrosino N, Bourbeau J, et al. American Thoracic Society/European Respiratory Society statement on pulmonary rehabilitation. Am J Respir Crit Care Med. 2006;173(12):1390-413. doi: 10.1164/ rccm.200508-1211ST.

6. Spruit MA, Singh SJ, Garvey C, ZuWallack R, Nici L, Rochester C, et al. An Official American Thoracic Society/European Respiratory Society statement: key concepts and advances in pulmonary rehabilitation. Am J Respir Crit Care Med. 2013;188(8):e13-64. doi: 10.1164/rccm.201309-1634ST.

7. Arnold E, Bruton A, Ellis-Hill C. Adherence to pulmonary rehabilitation: a qualitative study. Respir Med. 2006;100(10):171623. doi: 10.1016/j.rmed.2006.02.007.

8. Bulley C, Donaghy M, Howden S, Salisbury L, Whiteford S, Mackay E. A prospective qualitative exploration of views about attending pulmonary rehabilitation. Physiother Res Int. 2009;14(3):181-92. doi: 10.1002/pri.435.

9. Fischer MJ, Scharloo M, Abbink JJ, van 't Hul AJ, van Ranst D, Rudolphus A, et al. Drop-out and attendance in pulmonary rehabilitation: the role of clinical and psychosocial variables. Respir Med. 2009;103(10):1564-71. doi: 10.1016/j. rmed.2008.11.020.

10. Fischer MJ, Scharloo M, Abbink JJ, Thijs-Van A, Rudolphus $A$, Snoei $L$, et al. Participation and drop-out in pulmonary rehabilitation: a qualitative analysis of the patient's perspective. Clin Rehabil. 2007;21(3):212-21. doi: 10.1177/0269215506070783.

11. Rae S, White P. Swimming pool-based exercise as pulmonary rehabilitation for COPD patients in primary care: feasibility and acceptability. Prim Care Respir J. 2009;18(2):90-4. doi: 10.3132/ pcrj.2008.00052.

12. McNamara RJ, McKeough ZJ, McKenzie DK, Alison JA. Acceptability of the aquatic environment for exercise training by people with chronic obstructive pulmonary disease with physical comorbidities: Additional results from a randomized controlled trial. Physiotherapy. 2015;101(2):187-92. doi: 10.1016/j. physio.2014.09.002.

13. de Souto Araujo ZT, de Miranda Silva Nogueira PA, Cabral EE, de Paula Dos Santos L, da Silva IS, Ferreira GM. Effectiveness of low-intensity aquatic exercise on COPD: a randomized clinical trial. Respir Med. 2012;106(11):1535-43. doi: https://doi. org/10.1016/j.rmed.2012.06.022.

14. McNamara RJ, McKeough ZJ, Mckenzie DK, Alison JA. Water-based exercise in COPD with physical comorbidities: a randomised controlled trial. Eur Resp J. 2013;41(6):1284-91. doi: 10.1183/09031936.00034312.

15. Felcar JM, Probst VS, de Carvalho DR, Merli MF, Mesquita R, Vidotto LS, et al. Effects of exercise training in water and on land in patients with COPD: a randomised clinical trial. Physiotherapy. 2018;104(4):408-16. doi: 10.1016/j.physio.2017.10.009.

16. Chu KS, Rhodes EC. Physiological and cardiovascular changes associated with deep water running in the young. Possible implications for the elderly. Sports Med. 2001;31(1):33-46. doi: 10.2165/00007256-200131010-00003.

17. Chrystyn H, Small M, Milligan G, Higgins V, Gil EG, Estruch J. Impact of patients' satisfaction with their inhalers on treatment compliance and health status in COPD. Respir Med. 2014;108(2):358-65. doi: https://doi.org/10.1016/j. rmed.2013.09.021.

18. van der Palen J, Ginko T, Kroker A, van der Valk P, Goosens M, Padullés L, et al. Preference, satisfaction and errors with two dry powder inhalers in patients with COPD. Expert Opin Drug Deliv. 2013;10(8):1023-31. doi: 10.1517/17425247.2013.808186.

19. Yohannes AM, Woolryich R, Goldbart J, McGarrity-Dodd L, Hadri R, Quinn S, et al. Chronic Obstructive Pulmonary Disease Patients Service Satisfaction After Receiving Long-term Oxygen Therapy. Chest. 2011;140(4):534A. doi: 10.1378/chest.1117874.

20. Miller MR, Hankinson J, Brusasco V, Burgos F, Casaburi R, Coates A, et al. Standardisation of spirometry. Eur Respir J. 2005;26(2):319-38. doi: 10.1183/09031936.05.00034805.

21. Pereira CA, Sato T, Rodrigues SC. New reference values for forced spirometry in white adults in Brazil. J Bras Pneumol. 2007;33(4):397-406. doi: http://dx.doi.org/10.1590/ S1806-37132007000400008.

22. Cavalheri V, Hernandes NA, Camillo CA, Probst VS, Ramos D, Pitta F. Estimation of maximal work rate based on the 6-minute walk test and fat-free mass in chronic obstructive pulmonary disease. Arch Phys Med Rehabil. 2010; 91(10):1626-8. doi: https:// doi.org/10.1016/j.apmr.2010.07.002. 
23. Horowitz MB, Littenberg B, Mahler DA. Dyspnea ratings for prescribing exercise intensity in patients with COPD. Chest. 1996;109(5):1169-1175. doi: https://doi.org/10.1378/ chest.109.5.1169.

24. Barela AM, Stolf SF, Duarte M. Biomechanical characteristics of adults walking in shallow water and on land. J Electromyogr Kinesiol. 2006;16(3):250-6. doi: 10.1016/j.jelekin.2005.06.013.

25. Cohen D, Crabtree B. Qualitative Research Guidelines Project [Internet]. Somerset: University of Medicine and Dentistry, Department of Family Medicine; 2006 [cited 2021 Aug 16]. Available from: http://www.qualres.org/.

26. Heise D. The semantic differential and attitude research. In: Summers GF, editor. Attitude Measurement. Chicago: Rand McNally; 1970. p. 235-53.

27. Bardin L. Análise de Conteúdo. Lisboa: Edições 70; 2009.

28. Cote CG, Celli BR. Pulmonary rehabilitation and the BODE index in COPD. Eur Respir J. 2005;26(4):630-6. doi: 10.1183/09031936.05.00045505.

29. Probst VS, Kovelis D, Hernandes NA, Camillo CA, Cavalheri V, Pitta F. Effects of 2 Exercise Training Programs on Physical
Activity in Daily Life in Patients With COPD. Respir Care. 2011;56(11):1799-807. doi: 10.4187/respcare.01110.

30. Hornikx M, Van Remoortel H, Demeyer H, Camillo CAM, Decramer M, Janssens W, et al. The Influence of Comorbidities on Outcomes of Pulmonary Rehabilitation Programs in Patients with COPD: A Systematic Review. Biomed Res Int. 2013;2013:146148. doi: 10.1155/2013/146148.

31. Silva LK, Sena RR. Integralidade do cuidado na saúde: indicações a partir da formação do enfermeiro. Rev Esc Enferm USP. 2008;42(1):48-56. doi: 10.1590/S0080-62342008000100007.

32. Soufi G, Belayachi J, Himmich S, Ahid S, Soufi M, Zekraoui A, et al. Patient satisfaction in an acute medicine department in Morocco. BMC Health Serv Res. 2010;10:149. doi: 10.1186/1472-6963-10-149.

33. Beattie PF, Pinto MB, Nelson MK, Nelson R. Patient satisfaction with outpatient physical therapy: instrument validation. Phys Ther. 2002;82(6):557-65. doi: 10.1093/ptj/82.6.557.

34. Goldstein MS, Elliott SD, Guccione AA. The development of an instrument to measure satisfaction with physical therapy. Phys Ther. 2000;80(9):853-63. doi: 10.1093/ptj/80.9.853.

35. Minayo MCS. O desafio do conhecimento: pesquisa qualitativa em saúde. 8th ed. São Paulo: Hucitec; 2004. 